\title{
BOLETIM BIBLIOGRÁFICO
}

\section{ENDEREÇOS ÚTEIS NA INTERNET}

\section{http://www.sindicato.com.br}

Este é o endereço do Portal do Movimento Sindical na Internet. Contém informações úteis a todos que queiram saber um pouco mais sobre este importante movimento social. A página inicial contém as últimas notícias sobre privatizações, demissões, encontros etc. Ao navegar pelo portal, encontra-se um riquíssimo acervo de links com sites de diversos sindicatos, entidades e ONGs brasileiros. O usuário pode ainda ter acesso a artigos sobre globalização, neoliberalismo, história do movimento sindical no Brasil, anarquismo, comunismo e muito mais. Traz também artigos da Constituição Brasileira e a Consolidação das Leis do Trabalho, a CLT. Além disso, apresenta informativos das seções estaduais das centrais sindicais brasileiras.

http://www.sampa.org.br

O Projeto Sampa.org nasceu de uma iniciativa do Instituto Florestan Fernandes com o apoio da Prefeitura de São Paulo e de várias outras instituições com o objetivo de aumentar $\mathrm{e}$ facilitar $\mathrm{o}$ acesso da população paulistana às tecnologias de informação. $\mathrm{O}$ Sampa.org desenvolve projetos através de Pontos de Presença instalados em algumas instituições da cidade. Um dos mais atuantes Pontos de Presença também denominados de centros de cultura e informática funciona no bairro do Capão Redondo. Através do portal Sampa.org a população tem acesso ao Jornal Sampa.org - onde são publica- 
das notícias do projeto, da cidade, entrevistas - e à Agência de Notícias on line, organizada por jovens que freqüentam os Pontos de Presença e participam da organização comunitária na região. No portal, também é possível obter informações sobre os governos federal, estadual, municipal e administrações regionais da cidade de São Paulo.

\section{http://www.brasil-outros500.com.br}

Aproveitando as comemorações dos 500 anos do descobrimento do Brasil, diversas entidades ligadas a movimentos sociais - sindicatos, federações etc. - engajaram-se no projeto Brasil - Outros 500. Tal projeto tem o objetivo de contar o que não é lembrado pelos livros, além de divulgar movimentos sociais que têm dado uma colaboração importante à nossa história. Assim é que, navegando pela página, encontra-se a história das greves, da dívida externa, da relevante participação das mulheres na sociedade brasileira, do movimento de luta pela terra etc. Com isso a página torna-se uma alternativa para pesquisadores, professores, estudantes e demais pessoas interessadas em obter informações sobre fatos relevantes de nossa história e ter acesso a um outro ponto de vista sobre os 500 anos de formação do Brasil.

\section{http://www.secrel.com.br/jpoesia}

Faz algum tempo que a literatura invadiu a rede. Vários sites já disponibilizam obras literárias para serem lidas na telinha do computador. Seguindo esta tendência encontra-se o Jornal da Poesia. A iniciativa partiu do poeta cearense Soares Feitosa e já está no ar há quatro anos. Neste espaço é possível encontrar obras de mais de mil poetas brasileiros, bem como informações sobre eles, textos de crítica, entrevistas e endereços. A página também oferece links com alguns jornais do país.

\section{http://www.protagonismojuvenil.org.br}

Este é o endereço do Portal do Protagonismo Juvenil que surgiu no Distrito Federal, após um encontro promovido por centros ligados ao trabalho voluntário. O Protagonismo Juvenil é uma demonstração de que o jovem está mais atuante do que nunca junto à sociedade. No portal é possível acompanhar a atuação destes jovens protagonistas, incentivando outros projetos e promovendo a divulgação de vários trabalhos. Um dos contemplados é o Movimento de Intercâmbio Cultural pela Cidadania - MIAC, da Bahia (http://www.miac.org.br). Este movimento é uma parceria de escolas, fundações, centros culturais, de saúde etc. para promover a arte/educação. Em ambos os sites é possível obter informações sobre outros movimentos sociais. 
http://www.eca.usp.br/departam/cca/cultext/comueduc/rcabert.htm

O endereço é da revista Comunicação \& Educação cujo objetivo é divulgar as novidades no âmbito do debate sobre comunicação/educação. A revista conta com colaboradores nacionais e internacionais, enriquecendo a discussão sobre o tema e apontando novas perspectivas. Acessando esse site você encontrará um banco de dados com resumo, em português e inglês, de todos os artigos publicados nas revistas. Os artigos estão divididos por temas, autor e título. Também estão disponíveis no site o artigo de Apresentação, o Sumário e o Editorial, atualizados a cada número da revista. Os interessados em assinar Comunicação \& Educação poderão fazê-lo on line. 